\title{
Wage work and marriage: Perspectives of Egyptian working women
}

Sajeda Amin

Population Council

Nagah Hassan Al Bassusi

Follow this and additional works at: https://knowledgecommons.popcouncil.org/departments_sbsr-pgy

Part of the Demography, Population, and Ecology Commons, Family, Life Course, and Society Commons, International Public Health Commons, and the Quantitative, Qualitative, Comparative, and Historical Methodologies Commons How does access to this work benefit you? Let us know!

\section{Recommended Citation}

Amin, Sajeda and Nagah Hassan Al Bassusi. 2003. "Wage work and marriage: Perspectives of Egyptian working women," Policy Research Division Working Paper no. 171. New York: Population Council. 
Sajeda Amin

$\mapsto$

0 


\title{
Wage Work and Marriage: Perspectives of Egyptian Working Women
}

\author{
Sajeda Amin \\ Nagah H. Al-Bassusi
}

Sajeda Amin is Senior Associate, Policy Research Division, Population Council. Nagah $\mathrm{H}$. Al-Bassusi is an independent consultant, Cairo.

This paper was prepared for the Annual Meeting of the Population Association of America, Atlanta, 9-11 May 2002. The authors gratefully acknowledge Wesley Clark's invaluable research assistance, Sara Peracca's comments on an early draft, and comments from those attending an informal seminar at the Population Council. Funding for the project was provided by the Rockefeller Foundation, the International Development Research Center of Canada, and the United States Agency for International Development. 


\begin{abstract}
This paper explores young working women's perceptions of marriage and work in contemporary Egypt at a time when an increase in age at marriage was evident from national survey data. Data from two nationally representative labor surveys, the Labor Force Sample Survey of 1988 and the Egypt Labor Market Survey of 1998, show that working conditions and employment opportunities declined significantly for young women even as their educational attainment increased. Indepth interviews were conducted with young women working in a range of salaried jobs in three locations: a rural village in Mansoura, a periurban district near Cairo, and in the industrial zone of Port Said. The qualitative data indicate that young women have high expectations in terms of marital living standards that they seek to achieve by saving intensively before marriage and by enlisting help from their families.
\end{abstract}

This material may not be reproduced without written permission from the authors. For a list of Policy Research Division Working Papers, including those available for downloading in PDF format, see www.popcouncil.org/publications/wp/prd/rdwplist.html. 
This paper explores values and attitudes related to the competing roles of work and marriage among young Egyptian female wage workers in order to shed light on the impact of recent social change on women's lives. In the past several decades, age at marriage has increased considerably in Egypt, but relatively little change has occurred in employment opportunities for women. The relationship between work and marriage may be important for understanding a number of other phenomena related to gender roles, returns on education, and childbearing strategies. Modern marriage in Egypt may offer young girls something of greater value than the alternative of earning their own income through wage work.

A growing global literature exists concerning women's employment and marriage. Two streams in the literature are relevant for the questions central to this study. First, women's rising work-force participation and delayed marriage in the post-World War II period in the United States have been discussed intensely. The central controversy concerns interpretation and causality. Becker (1991) argued that in the past, marriage was a product of spousal specialization whereby each partner adopted the roles for which he or she had superior skills. As a result men specialized in market work and women in domestic work. The social arrangement that resulted from this system has come under threat as a result of economic growth and increasing opportunities for women. Marriage is rendered less essential in economic terms as women become financially independent. Oppenheimer (1997) offered an alternative and less stark view of women's situation. She argued that economic independence can raise women's expectations about acceptable living standards and provide benefits to marriage generally as women contribute to household finances. Sixteen years earlier, Waite and Spitze (1981) examined the determinants of changing proportions married in the United States and found that the availability to women of attractive alternative roles explained the probability of marriage. They also found, however, that parents bring normative pressures to bear on their children's choices that prevent them from making undesirably early or late marriages. Sassler and Schoen (1999) explored US longitudinal data and showed that in addition to changes in economic opportunity, the independent effects of values and attitudes explain sex and race differences in attitudes toward marriage. More positive attitudes are associated with earlier and higher marriage rates. Thus, a body of evidence is 
emerging that shows how social and cultural factors, in particular changing attitudes and norms, temper the harsh economic tradeoffs between women's independence and the benefits they gain from marriage.

A second set of considerations emerged from the writings of Caldwell (1982) and others who argued that normative change plays an important role in explaining changes in the characteristics of marriage. These normative changes usually accompany structural alterations in the economy, but can come about even in their absence through the influence of Western ideas and the spread of mass education, both of which promote Western family values, including the nuclear family structure, late marriage, and individual choice of partner. Malhotra and Tsui (1996), exploring the role of modern ideas in explaining the timing of marriage in Sri Lanka, found considerable resilience in traditional cultural values as they affected the coexistence of family life and higher education and late age at marriage for women. A number of other studies also support the thesis that societies operate in considerably more complex ways than the neat dichotomy of modernization theory predicts. Analyzing and understanding the context and process of change can be crucial for predicting the course of future change.

\section{THE EGYPTIAN SETTING}

\section{Timing of Marriage}

Egyptian trends in the timing of marriage have followed patterns observable in the surrounding countries of West Asia and North Africa. In most countries of the region, marriage takes place at relatively late ages. A comparative analysis of trends suggests, however, that change in age at marriage has been slower in Egypt than in Kuwait, Lebanon, Libya, and Sudan (Rashad and Osman 2000). An earlier comparative analysis of marriage age showed a pattern of later marriage in this region compared with subSaharan Africa and South and East Asia, with average ages at marriage for the region only slightly lower than those of Latin America (Smith 1980).

An analysis of fertility and related patterns in Egypt led Coale (1989) to conclude that age at first marriage first began to decline sometime in the late 1960s and early 1970s. An in-depth study in neighboring Sudan in the mid-1970s documented a general- 
ized and rapid increase in women's age at marriage in the ten-year period preceding the survey (Abdelrahman and Morgan 1987).

Table 1 shows proportions of the Egyptian population who were single in selected years between 1947 and 1998, and confirms that a sharp decline occurred between 1966 and 1976 in the proportions who married at young ages. Coale cited the mass mobilization for the war effort as a possible reason for this shift, but other factors that may have sustained the pattern of later marriage were the migration of men, girls' rising school attendance, and the introduction of electricity and television in rural communities. During the decade of the shift, little change was evident in the pattern of wage work among women or in the reporting of their participation in economic activities. Therefore, during that period no link was seen between the change in wage work and the shift in marriage patterns. To the extent that salaried employment helps to pay for the costs of setting up a new household, it may even be associated with earlier marriages. Rashad and Osman (2000) concurred with the evidence presented in Table 1 that more recent trends show a continuation of the pattern of delayed marriage.

Singerman and Ibrahim (2002) suggested that rising age at marriage is a consequence of declining economic opportunities for men coupled with increased costs of marriage. Several other analyses of marriage in Egypt also documented a pattern of increased expenses in the form of material acquisitions that are considered necessary for a couple beginning their marriage (Singerman and Hoodfar 1996; Hoodfar 1997). Two aspects associated with modern marriage are identified. First, newly married couples now are more likely to aspire to live in their own household after marriage, and both bride and groom are expected to contribute to the setting up of their household. Second,

Table 1 Proportion of women and men aged 15-24 who were single, by age group, Egypt, 1947-98

\begin{tabular}{|c|c|c|c|c|c|c|c|c|c|c|}
\hline \multirow[b]{2}{*}{ Age group } & \multicolumn{5}{|c|}{ Women } & \multicolumn{5}{|c|}{ Men } \\
\hline & 1947 & 1966 & 1976 & 1988 & 1998 & 1947 & 1966 & 1976 & 1988 & 1998 \\
\hline $15-19$ & 0.59 & 0.66 & 0.78 & 0.78 & 0.89 & 0.87 & 0.93 & 0.96 & 0.99 & 0.99 \\
\hline $20-24$ & 0.20 & 0.23 & 0.39 & 0.43 & 0.56 & 0.69 & 0.75 & 0.80 & 0.82 & 0.99 \\
\hline
\end{tabular}

Source: UN Demographic Yearbooks, various years. 
the level at which a couple is expected to live has risen as their access to durable goods has increased. Traditional negotiations are deployed for the attainment of the goal of setting up a nuclear household as a newly married couple. A partial commitment is made by having an engagement, and an agreement is reached as to what each party will contribute. As standards of living rise and the resources used for the accumulation of household goods multiply, the length of the engagement period is reported to be lengthening. The average cost of such acquisitions in the late 1990s is estimated to have been several times the average household budget.

For a young woman, wage employment is one way of meeting these costs, but work does not necessarily provide a definite edge over alternative strategies. The expense of setting up a new household, to which the bride may contribute, is assumed by her entire family. The groom is expected to provide housing and major items of household furniture. The bride brings the china, kitchen appliances, and utensils, and may bring some items of furniture. The assets brought to a household by each partner are detailed in a list, and the marriage contract is drawn. The contract is considered incomplete unless the list is agreed upon by both parties and ownership of assets brought to the marriage is established.

Thus, the timing of marriage is closely tied to rising material expectations and to increased consumerism, which in turn are a result of economic expansion (Singerman and Ibrahim 2002). Ideally, young couples are expected to accumulate sufficient resources before they marry to set up their own household after marriage, a radical departure from the recent past, when a new couple typically began married life as part of an extended household. In fact, however, the extended household arrangement persists for a sizable proportion of newlyweds. Fewer than one in three married men between the ages of 15 to 24 are heads of their own household (authors' calculation from the Egypt labor-force survey of 1998).

Rising consumerism was fueled by the opening up of the economy as part of Egypt's structural adjustment policies following a closed regime of import substitution. Liberal import and export laws brought imported appliances and cars and, more recently, cell phones, computers, and a large array of consumer goods. Many of these changes in values and aspirations are also attributed to high levels of labor migration of 
Egyptian men to the Gulf States following the economic expansion that occurred after the 1974 oil crisis. Throughout the 1970s and 1980s, many Egyptian families were supported by remittances from abroad. Economic aspirations and living standards likely were driven by a sudden increase in income without a concomitant rise in opportunities in the domestic economy. The prevalence of remittance income is held responsible for altering the taste for and affordability of consumer durables and for elevating standards of living for the families of migrant laborers.

After more than ten years of remittance-fueled economic and social change, opportunities began to shrink, and by the 1990s a large number of migrant workers returned while few new opportunities opened up in the domestic economy. Some of the social and economic legacies of this period of large-scale migration are still evident. Elevated material aspirations among newlyweds continues to be the norm. Young women in the study sample living in humble abodes in rural villages speak of not marrying until they have a two-door refrigerator, a washing machine, and a gas stove.

International migration may have led also to a reevaluation of household structure and family life as large numbers of women were left behind to manage households. This change in women's status was magnified by increases in girls' educational opportunities. At the same time that migration to the Gulf states fueled greater consumerism and a higher standard of living, it exerted a conservative pressure. The Gulf states are generally more socially conservative than Egypt, and migrants returning from the Gulf, although they were better-off financially than they had been, may have brought back elements of this more conservative culture. They may even have been conduits of a new brand of Islam, labeled "Saudi Islam." In other parts of the world that have experienced similar streams of migration to the Middle East, the same changes in religious culture are attributed to Arab influences. Interestingly, similar changes are noted and recognized within Arab countries as well. During this time, certain external manifestations of religious observance, such as women's wearing of scarves and veils, have become more common. Another anecdotal indicator of an increase in Islamic cultural practices in Egypt is in naming conventions: Egyptians are more likely now to be given Islamic names, and the form of social observances such as wedding parties and birth celebrations have also changed to incorporate Islamic religious symbols. 
This study explores data on work and marriage during a time of structural adjustment and reforms to the economy that took place with much fanfare. Structural adjustment policies that came into effect in the late 1980s have been a source not only of optimism but also of some concern for their far-reaching effects on the labor force. These policies were expected to affect young women disproportionately and positively. The policy of encouraging private investments in the export of garments, textiles, and electronics was expected to increase employment of large numbers of young women, even in conservative Egypt as it had done elsewhere. Rapidly growing export-led sectors have in fact played an enormous role in expanding women's wage-work opportunities (Wolf 1992; Amin et al. 1998). Aspects of these policies that cause concern are shrinking social-sector investments in education and health, retrenchment in publicsector enterprise, and the privatization of state-owned businesses, as well as rising inequality and consumerism. In practice, the structural adjustment policies of Egypt have progressed slowly and fitfully, with industrial export zones limited primarily to low-end garment production. Because most zones are located at a distance from densely populated areas, they have done little to lower rising overall unemployment rates.

\section{METHODOLOGY AND DATA}

Quantitative data for this study are drawn from two nationally representative labor-force surveys conducted ten years apart and designed to facilitate a comparison of data from the two surveys. The two surveys were conducted at the same time of year and implemented by Egypt's national statistical institute, the Central Agency for Public Mobilization and Statistics (CAPMAS). The Egypt Labor Market Survey was conducted in October 1998 in collaboration with the Economic Research Forum for Arab Countries, Turkey, and Iran and was designed using a sample and instruments similar to those used in the special round of the Labor Force Sample Survey undertaken in October 1988.

The 1998 sample consists of 5,000 households in 200 primary sampling units. Large metropolitan areas of Cairo and Alexandria were oversampled to include more women engaged in salaried employment in the private sector. Appropriate weights were used to obtain regional and national levels. Of a total of 23,997 individual household members observed in the 1998 survey, 22 percent $(5,175)$ are between ages 15 and 24 
(2,737 males and 2,438 females). The 1988 survey recorded 28,286 individual observations, of which 20 percent $(5,597)$ were collected from respondents between ages 15 and 24 (2,888 males and 2,709 females).

The Population Council developed the youth model incorporated into the Egypt Labor Market Survey and also conducted a qualitative study of young female wage workers. The case studies were based on in-depth interviews conducted during multiple visits to respondents' households. Interviews were transcribed, translated, and summarized into short case histories for analysis by the research team. The qualitative cases include female workers in the private sector from three locations in northern Egypt: the periurban community of Ain-Helwan near Cairo, an investment zone on the coast, and a rural village in the district of Mansoura in Dakahlia governorate. The respondents worked in three occupational categories: garment manufacturing in an industrial zone, sales and services in an urban area near Cairo, and small factories in Mansoura city, Dakahlia governorate. The interviews were conducted between 1998 and 2000 with women who had had experience working in the private sector in formal, full-time jobs.

To the extent possible, a random selection process was implemented to obtain respondents within the chosen study sites. In the industrial zone, this process came closest to a true random selection, because the authorities in the zone maintain a fairly complete listing of all individuals who have worked in any of the factories in the recent past. Respondents were selected randomly from this list and located by the addresses included in the roster. In the Greater Cairo location, the investigators used a complete listing of households provided by a nongovernmental organization (NGO) working in a public housing area. This listing permitted a random selection of households to be made, members of which were contacted and briefly questioned in order to locate young women who were engaged in salaried work. During the sample-selection process in Mansoura, investigators elicited the help of an NGO providing microcredit services to adolescent girls and women. The organization's roster of eligible individuals included women engaged in wage work who could be contacted. Although the selection process is by no means entirely random, it was designed to prevent a self-selection of more articulate respondents that would bias the profiles. The total number of interviews conducted in each site was influenced by our assessment of the usefulness of additional interviews. 


\section{TRENDS IN WAGE WORK IN EGYPT}

Examination of data on changes in workforce participation between 1988 and 1998 reveals that — contrary to expectations that policy reforms during structural adjustment had expanded opportunities for young women-opportunities declined slightly during that decade. During this period, marriage was considerably delayed as shown in Table 1. Figure 1 compares the distribution of young people (married and unmarried) aged 15 to 24 according to their school enrollment and labor-force participation in 1988 and 1998. Figure 2 shows the same variables for unmarried young people. The proportion of all 15-24-year-olds in our sample attending school increased from 27 to 38 percent for women and from 38 to 45 percent for men. Because attending school and working for wages tend to be mutually exclusive, and few women report doing both, the rise in education effectively shrinks the proportion who can potentially join the labor force. At the same time, the age pattern of marriage shows a delay. The proportion married among women aged 15-24 dropped from 36 percent to 24 percent (not shown). Because getting married is closely associated for women with dropping out of the labor force, the net effect of a 9 percentage point increase in school attendance on labor-force participation is offset by a 12 percentage point decline in the number who are married. Among

Figure 1 Percent distribution of women and men aged 15-24, according to school enrollment and labor-force participation, Egypt, 1988 and 1998

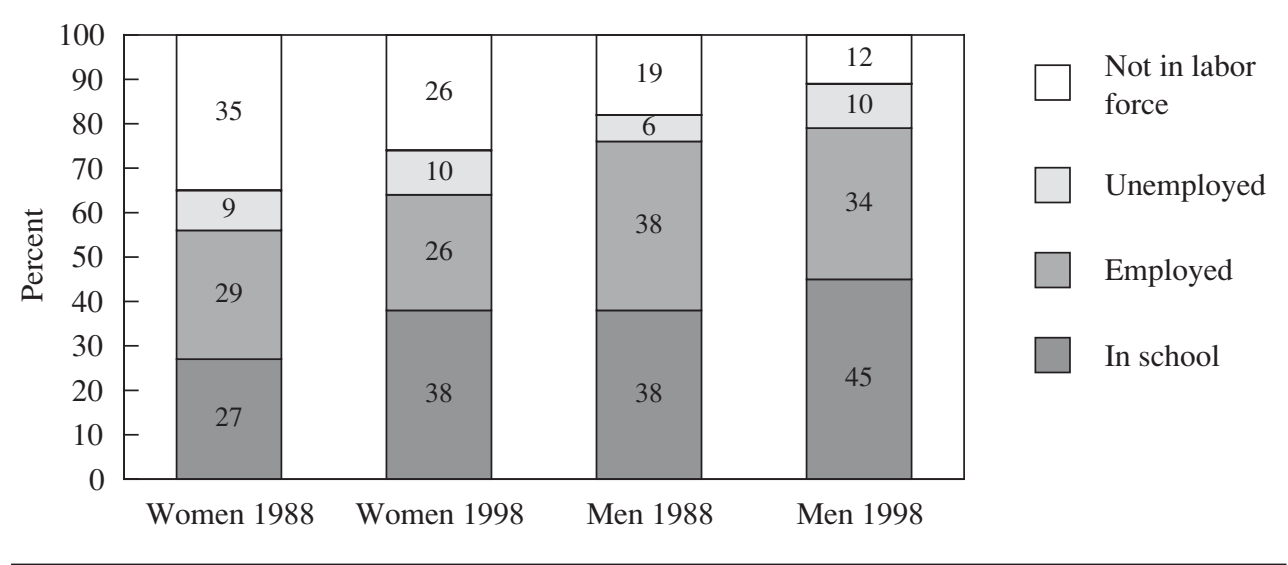


Figure 2 Percent distribution of unmarried women and men aged 15-24, according to school enrollment and labor-force participation, Egypt, 1988 and 1998

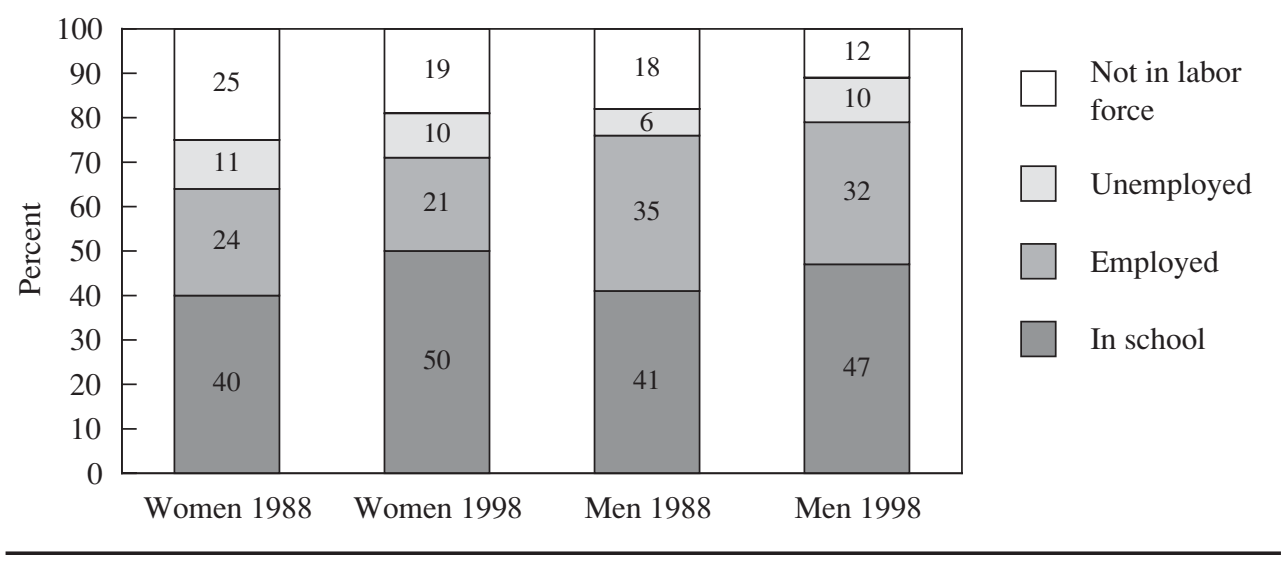

unmarried women, the proportion not in the labor force declined from 25 percent to 19 percent among unmarried girls (Figure 2).

Table 2 presents estimates of the total number and proportions of paid ${ }^{1}$ female workers aged $15-29$ by sector, based on the nationally representative sample surveys of 1988 and 1998. Egypt's labor force is expanding at a rate of more than 2 percent annually, and the number of females aged 15-29 in the labor force increased from 6.7 million to 8.2 million in the decade between 1988 and 1998. Sales jobs increased from 69,000 to 106,000. The total number of paid jobs in all other sectors declined in absolute terms, however, with the greatest numerical decline occurring in the agricultural sector.

Part of the decline in the number of girls holding jobs may have been the result of an increase in school enrollment. To allow for distributional differences between the two surveys in background and other characteristics, we estimated probabilities of being enrolled in school and of being employed using multinomial logistic regression models that control for compositional differences between the two surveys. These models suggest that the probability that a young woman would be gainfully employed was lower in 1998 than in 1988 (see Figure 3).

To obtain another picture of the probability of employment, we estimate a logistic model using pooled data from the two surveys (shown in Table 3). Although the 


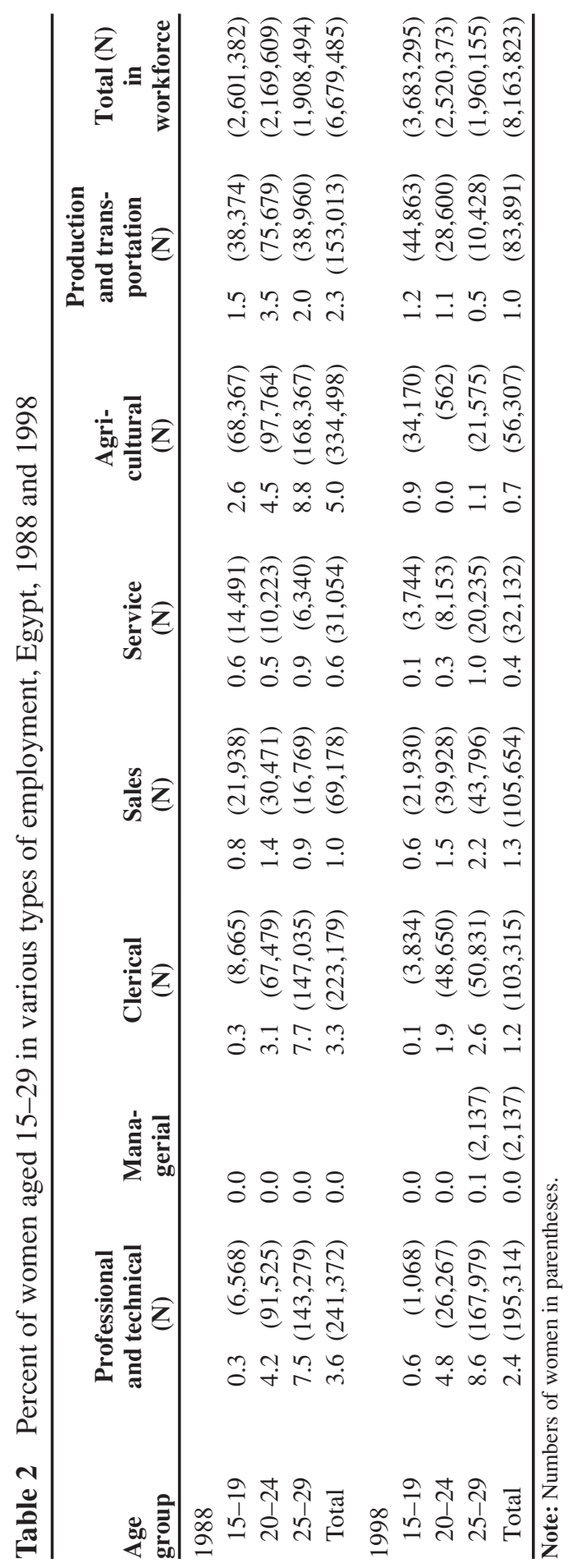


model does not allow for endogeneity and should be interpreted with caution, it confirms that the probability of being engaged in paid employment was lower for respondents interviewed in 1998 compared with those surveyed in 1988. Young women engaged in salaried work in 1998 are different from their peers: they are more likely to be educated, but less likely to be in school or married. The probability of being employed in wage work increases with age. Women living in urban Upper Egypt have a lower probability of working for wages. Parental education and occupation do not appear to influence the proportion of young people who are engaged in employment for wages.

Thus, contrary to the expectations for a period of structural adjustment, a decline occurred in paid employment opportunities even for young women. Although structural adjustment policies were designed to encourage new jobs for women, especially in sales and export-oriented industry, these did not compensate for the simultaneous loss of opportunities in the public sector and in paid agriculture. The net result of structural adjustment has been that among women in particular, the private sector now accounts for a greater share of jobs than either the agricultural wage-work sector or the public sector (see Figure 4).

Figure 3 Percent probabilities that women aged 17 and 22 are enrolled in school or employed, Egypt, 1988 and 1998

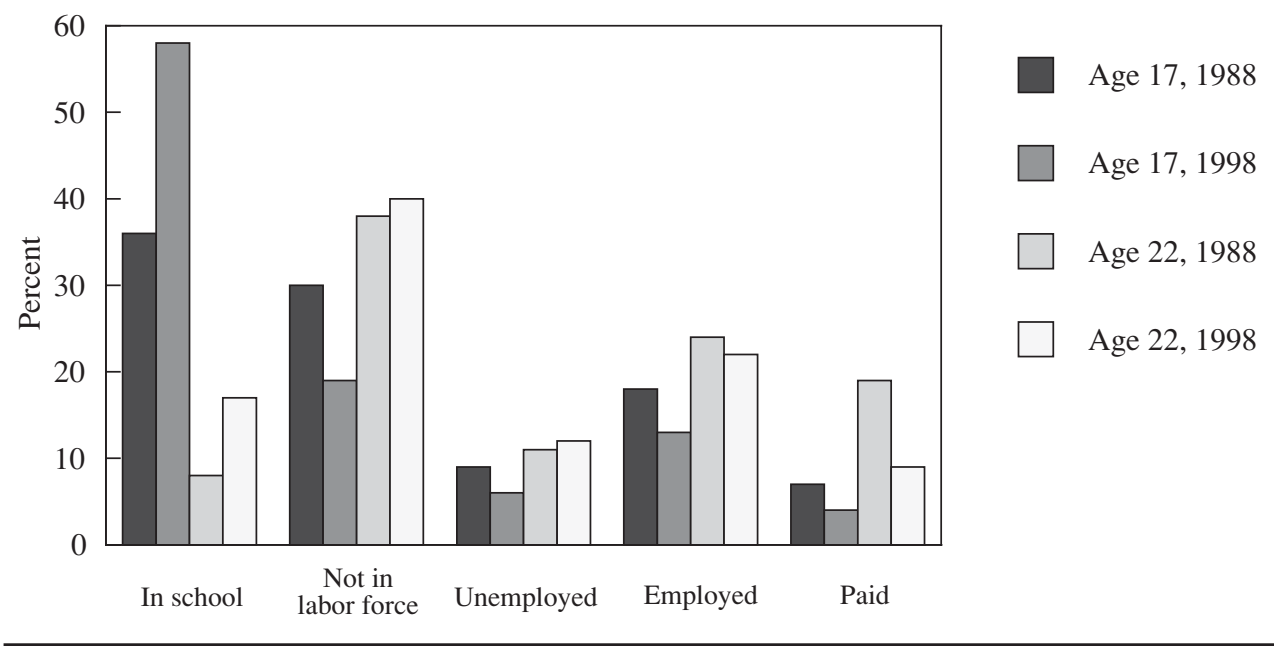


Table 3 Logistic regression showing likelihood of participation in paid employment by women and men aged 15-24, according to selected characteristics, Egypt, 1988 and 1998

\begin{tabular}{|c|c|c|c|c|}
\hline \multirow[b]{2}{*}{ Variable/category } & \multicolumn{2}{|c|}{ Women } & \multicolumn{2}{|c|}{ Men } \\
\hline & $\beta$ & $\begin{array}{c}\text { Significance } \\
\text { level }\end{array}$ & $\beta$ & $\begin{array}{c}\text { Significance } \\
\text { level }\end{array}$ \\
\hline \multicolumn{5}{|l|}{ Mother's education } \\
\hline Read and write only & -0.22 & 0.27 & -0.09 & 0.56 \\
\hline Illiterate $(r)$ & 1.00 & - & 1.00 & - \\
\hline Less than intermediate & -0.02 & 0.95 & -0.41 & 0.02 \\
\hline Intermediate or higher & 0.58 & 0.04 & -0.13 & 0.59 \\
\hline \multicolumn{5}{|l|}{ Father's education } \\
\hline Read and write only & 0.25 & 0.09 & 0.09 & 0.42 \\
\hline Illiterate (r) & 1.00 & - & 1.00 & - \\
\hline Less than intermediate & 0.17 & 0.40 & -0.16 & 0.27 \\
\hline Intermediate or higher & 0.09 & 0.71 & -0.09 & 0.63 \\
\hline \multicolumn{5}{|l|}{ Father performs agricultural work } \\
\hline Yes & -0.09 & 0.61 & -0.25 & 0.04 \\
\hline No $(r)$ & 1.00 & - & 1.00 & - \\
\hline \multicolumn{5}{|l|}{ Father performs wage work } \\
\hline Yes & 0.28 & 0.03 & 0.28 & 0.01 \\
\hline No (r) & 1.00 & - & 1.00 & - \\
\hline \multicolumn{5}{|l|}{ Region } \\
\hline Alexandria/Canal cities & 0.16 & 0.43 & -0.52 & 0.00 \\
\hline Urban Lower Egypt & -0.40 & 0.04 & -0.31 & 0.03 \\
\hline Urban Upper Egypt & -0.52 & 0.02 & -0.35 & 0.02 \\
\hline Greater Cairo $(\mathrm{r})$ & 1.00 & - & 1.00 & - \\
\hline Rural Lower Egypt & 0.03 & 0.88 & -0.61 & 0.00 \\
\hline Rural Upper Egypt & -0.09 & 0.67 & -0.22 & 0.15 \\
\hline \multicolumn{5}{|c|}{ Respondent has intermediate or higher education } \\
\hline Yes & 0.64 & 0.00 & -0.60 & 0.00 \\
\hline No (r) & 1.00 & - & 1.00 & - \\
\hline \multicolumn{5}{|l|}{ Respondent enrolled in school } \\
\hline Yes & -2.66 & 0.00 & -2.88 & 0.00 \\
\hline No $(r)$ & 1.00 & - & 1.00 & - \\
\hline \multicolumn{5}{|l|}{ Respondent currently married } \\
\hline Yes & -0.70 & 0.00 & 0.58 & 0.00 \\
\hline No (r) & 1.00 & - & 1.00 & - \\
\hline Age & 0.19 & 0.00 & 0.05 & 0.01 \\
\hline Respondent interviewed in 1998 & -1.11 & 0.00 & -0.13 & 0.18 \\
\hline Respondent interviewed in 1988 (r) & 1.00 & - & 1.00 & - \\
\hline Missing all parental data & -2.34 & 0.00 & 0.018 & 0.94 \\
\hline Missing father's employment data & -0.13 & 0.60 & 0.144 & 0.36 \\
\hline Missing in/out of school data & 0.22 & 0.62 & -1.36 & 0.00 \\
\hline
\end{tabular}

$(\mathrm{r})=$ Reference category. $\quad-=$ Not applicable.

Note: Data are pooled. 
Figure 4 Percent distribution of women and men aged 15-24 employed in wage work, by type of work, Egypt, 1988 and 1998

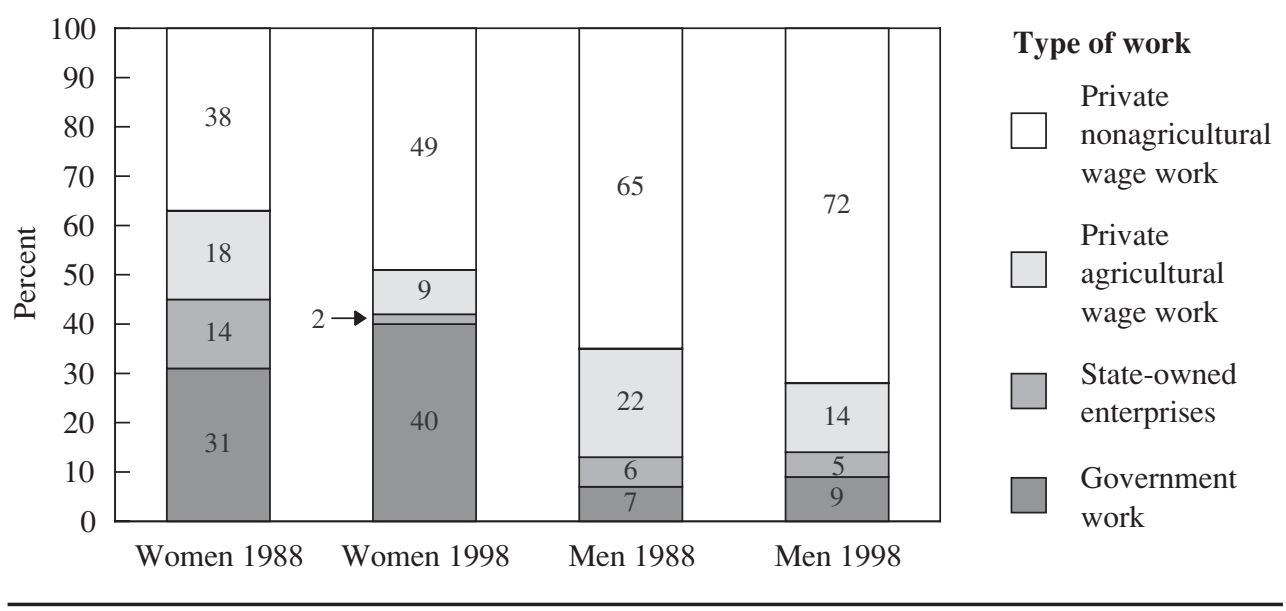

Figure 5 presents an overview of changes in the nature of employment in the private sector as measured by the proportion of jobs offering contracts, medical insurance, or social security. In 1998, young people worked in private-sector jobs that were

Figure 5 Percent of women and men aged 15-24 employed in private-sector jobs that offer contracts, social security, or medical insurance, Egypt, 1988 and 1998

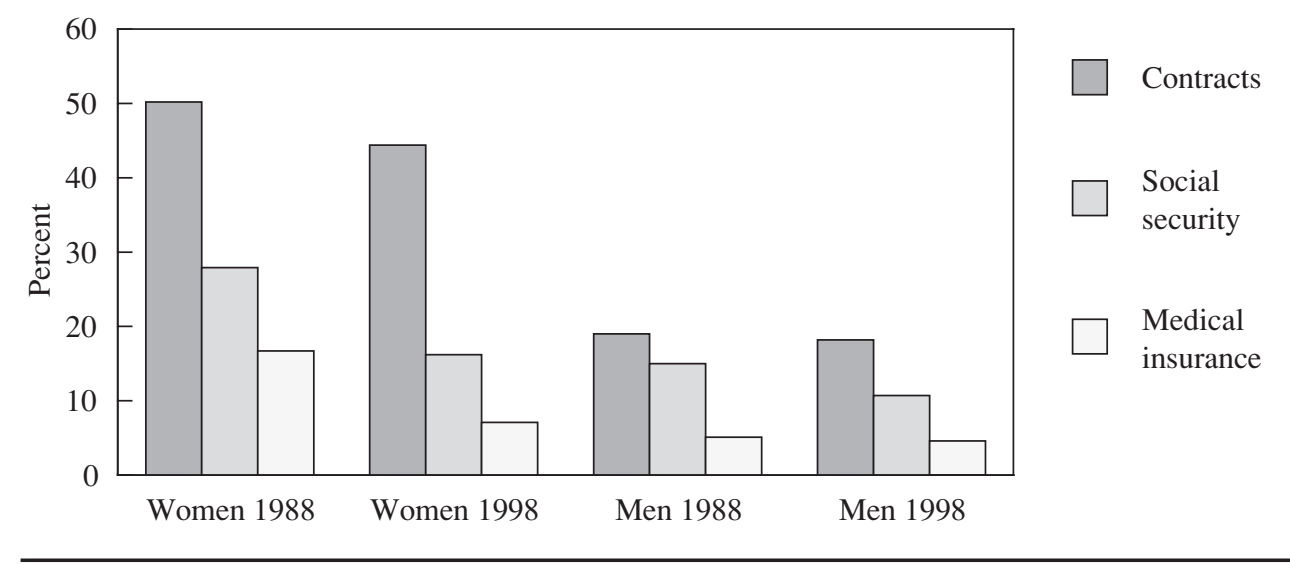


considerably less likely than was the case in 1988 to provide contracts, social security, or medical insurance. In the past, as in 1998, however, women held better jobs than men did in terms of these measures. Finally, the data concerning hours of work (shown in Table 4) revealed that women worked considerably longer hours overall in 1998 compared with 1988.

\section{WOMEN'S ATTITUDES TOWARD WORK AND MARRIAGE}

Women reported overwhelmingly that a primary reason they took a job was to prepare for marriage. Marriage in Egypt is usually a matter of family negotiation regarding choice of partner and timing of wedding. Although Demographic and Health Survey (DHS) data suggest that most Egyptian marriages are between kin, such marriages appear to be less common among women who have worked for wages, according to our calculation from DHS data. The descriptions of individual experiences reported below suggest that working women are often actively involved in the process of searching for a spouse and that they exercise some control over the decision in direct and indirect ways.

By and large, women and their families believe that marriage is facilitated by work and that working girls are more likely than unemployed girls to be married at the appropriate time. Being a wife and holding a job are not seen as competing roles, however, because women are expected to quit working after they marry. Future spouses are not expected to accommodate themselves to a wife's career aspirations, and a young bride typically is expected to spend most of her time performing domestic chores.

Table 4 Average number of hours worked per week among salaried women and men aged 15-24, by type of work, Egypt, 1988 and 1998

\begin{tabular}{lcccccccc}
\hline & \multicolumn{3}{c}{$\mathbf{1 9 8 8}$} & & \multicolumn{3}{c}{$\mathbf{1 9 9 8}$} \\
\cline { 2 - 4 } Type of work & Women & Men & Total & & Women & Men & Total \\
\hline Government & 35 & 39 & 37 & & 39 & 46 & 43 \\
State-owned enterprises & 44 & 51 & 48 & & 55 & 51 & 51 \\
Private agricultural wage work & 40 & 37 & 38 & & 71 & 40 & 44 \\
Private nonagricultural wage work & 51 & 48 & 49 & & 53 & 53 & 53 \\
Total & 43 & 45 & 45 & & 49 & 51 & 51 \\
\hline
\end{tabular}

Source: Labor Force Sample Survey 1988 and Egypt Labor Market Survey 1998. 
Despite the trend toward later marriage observable in the data, the narratives presented below show that notions about the appropriate age for marriage remain rigid among working women and their families. To accommodate this increasing gap between aspirations regarding timing of marriage and the reality of later marriages, engagement periods are becoming longer. The most desirable age for a young woman to become a bride or to be betrothed is around 20. This idea of an optimal age at marriage seems to be related to the notion that a young woman reaches her prime at that time; the idea does not appear to be conditioned in any way by her work status. Rather, the emphasis lies on how she is perceived by those who might bid for her hand. As the mother of a young worker remarked:

My mother-in-law used to say that a girl has a market value, and we should be quick to get her married before her market value goes down. The girl is like a buffalo; this man wants her and this [one] wants her, and if you don't choose one of them, you are going to lose them all, you are going to lose the peak of her market value, and she will be left. If the girl gets close to her market value, give her to her buyer.

As described above, specific expectations exist regarding the material goods that a bride and groom should bring to their marriage. Among the survey respondents little variation was found in terms of what these expectations were either among individuals or across geographic areas, although the three areas differed significantly in terms of the opportunities they provided for work and in household standards of living. The reasons and explanations given for the importance of the gehaz (trousseau) were varied and covered a range of factors from considerations of social status to the need to conform. Respondents also emphasized concern for the well-being of the bride in her marital family. Some of the explanations respondents gave concerning the logic of spending on the gehaz are presented below.

Here in the village, we have a special celebration of the gehaz. We put every piece of the gehaz on open cars that go around the village several times (with music) in order to show off the gehaz. This is to announce the wedding and show everybody how good the gehaz is. So I will honor [my 
daughter] and show everybody that she is no less prepared than any other girl in the village. We already bought her china, a fridge, and a breadmaking machine. We also bought kitchenware and some of her clothes.

(Mother of a respondent in Mansoura)

The girl's gehaz is ritualized to make its content public knowledge, and, as the quotation above indicates, the purpose of making this information public is to benefit the bride by displaying her family's wealth, presumably to enhance her status within her new marital family. The assumption is that the more assets she brings to her new household, the better will be her bargaining position. A working woman who is not yet married reinforced this function of the gehaz:

In order to keep my dignity, I have to prepare myself as well as I can. The cupboard of the dining room has to be full of china sets that I will never use, but I cannot keep my head above my shoulders if I do not buy it. (Abeer, Port Said)

Several respondents indicated a more direct and economically functional aspect of the gehaz, relating it to the future costs of rearing a family. The mother of a rural respondent remarked:

Men like to marry girls who are rich or at least prepared well. I will tell you why: After one year of a marriage, they will get a child. The new child needs a budget for him only (clothes, diapers, doctors, milk, medicine, and so on). Also a couple needs a budget for food, clothes, doctors, medicine, rent, compliments [gifts], and so forth. In the second year, they may receive their second child who needs another budget. Some years later the children will go to school and need a new budget. The wife has to stay at home in order to take care of the children. Do you think the salary or whatever type of earnings that the husband makes will enable him to do all that and more? This means the couple will not have a chance to prepare themselves after they are married. They have to start as perfect as possible, because there is no other chance to improve their living standard later. 
This explanation suggests that the need to accumulate extensive material holdings before marriage is tied to inflexible expectations regarding childbearing. Although age at marriage is increasing, the need to establish fertility soon after marriage remains important. Even in countries that have recently experienced a transition to later age at marriage, the first-birth interval remains rigid (Mensch et al. 1998).

With regard to marital expectations, discussions with respondents indicated that considerations of individual preferences and the quality of interpersonal relationships are reasonably well articulated. The interviewers asked young women what they were seeking in a husband. They received clear and direct but varied answers on what qualities are deemed important. The responses are surprising in their explicitness, considering that in Egyptian society arranged marriages, often between relatives, are still the norm. The nature of the responses also suggests that women have some say in whom and when they will marry.

Some young working women responded to the questions about desirable qualities in a husband as follows:

I need him not to be tall and not to be short, but I want someone a little bit fat (I don't like thin people). I want dark skin. I would like his salary to be high, maybe 100 pounds a week. But really, the important thing is that I would like to be happy.

There should be love, that is important, but I don't accept the way it is practiced and understood by the society and by men. Before, it was very unusual for a man to go and propose to a girl to engage and date just to have a chance to date, but now they do all that and get into the house just to date.

It is important to respect. [One] should not be controlled by the heart only, but also by the mind; real love is respect. If he is a real man, he will not abuse or exploit the girl.

A strong refrain of pragmatic considerations is also evident in responses about marriage. In the following remark, a respondent describes characteristics that are impor- 
tant to her in a groom. She prefaces her pragmatism by showing that she has considered the alternative of marrying for love. She rejects a love match because of the intrinsic differences she observes in how men and women view love.

I don't believe in love. The only kind of love [I know] is for my mother and sister. I don't have any experience in the other kind of love. Men are not respectful. A man who was proposing to me asked me: Do you know what attracted me to you? It is your body. See, it is desire; it is not love. I want to marry a man who is rich, successful, and able to take responsibility. He should be older than 20 years, one who has fixed monthly income. I would like the man to be prepared and ready for marriage, not one who has a room or who is still looking for a flat, or one who is going to live with his mother.

As noted above, working women are considerably more likely to marry outside the family. The survey respondents represented a range of circumstances in which matches are made for modern-day Egyptian women, and their comments describe how having jobs may allow men and women to pursue a new kind of search for a marriage partner. Although the workplace can be an important place to meet a future spouse, family connections and gatherings and neighborhood acquaintances continue to provide working women with a range of options. Women's comments show that they feel they can exercise some measure of control over a proposed marriage, even if it is formally arranged by their families. Even in marriages made according to women's and men's own choice, the rules they use to assess a partner are the same as those governing an arranged marriage. In other words, arranged and love marriages may not differ greatly in form and function.

The following remarks from the same group of women illustrate a variety of marriage circumstances among the survey respondents:

He works in the same hospital [as I do] as a sanitary supervisor. He liked me, tested me, and found me polite. So he proposed and we got engaged.

He was my brother's friend and a neighbor. He proposed, and we did not go out before marriage. 
We were neighbors. We used to talk to each other from the balcony. Yes, I did go out behind my parents' backs. We dated for a year before we got married. We met maybe every Friday.

There was someone [I loved before marriage], but he said his circumstances were not good for him so he could not propose. I went out for one year; I met him through an aunt. He met me there and called me on the phone, and sometimes by chance I saw him.

I was engaged to my cousin about three years ago. My father refused to let us go out. [My cousin] did not like that. He wanted me with him all the time, and I didn't like that. Once he came to me at the museum [where I work] and I didn't like that. In fact, I did not love him. I did not treat him the way he would like [and the engagement was eventually called off].

Regardless of whether or not respondents were presently engaged, all of them spoke of how they were saving or preparing for their marriage with the expectation of carrying a substantial trousseau to the new home. For a number of workers, saving for large wedding items involved going into debt. Usually, women and their families use a traditional social custom of joining rotating savings pools in order to make these large purchases (Hoodfar 1997).

As an example, Aisha of Helwan pays 45 pounds a month from her salary for transportation and saves the rest for her marriage trousseau. She explained that the gehaz is an expensive undertaking for her parents, so she works to save in order that her marriage will not be a burden to her parents. Another respondent, Abeer, a factory worker in the investment zone who was recently married, reported that she contributed 3,000 out of the 8,000 pounds required for her marriage. One of the items she acquired and was proud to show was an ornate sideboard for the dining room.

The mother of a respondent in Greater Cairo who has two daughters younger than 18 said she had opened a postal savings account in her own name for each of them because they had not reached the age at which they could open such an account legally. The money saved is to be used to help with their marriage preparations. One of her daughters is engaged, and the family will soon start using the savings to buy items for her gehaz. 
Similarly, another respondent who earns 120 pounds a month said that she pays 12 pounds for transportation, and about the same for lunch. She estimated that she has saved almost 100 pounds each month, which she gives to her mother for her marriage preparations.

Significantly, none of the discussions with wage-earning women reflected any sense that they were postponing marriage because of their need or desire to work. Several respondents described a tradeoff, however, between education and work because of thoughts about marriage. A Port Said respondent reported that she thought working after receiving her diploma was better than studying for two more years. Starting to work immediately would enable her to begin preparing for marriage and make things easier for her family. If she continued her education, she would graduate at 20 , the age at which she expected to be married, and she would not have an opportunity to save for her marriage. Also, she felt that by obtaining a higher degree, she would actually lower her marriage prospects:

If I went on to an institute [of higher education], I would want to marry a man with at least the same degree, if not higher, and it would be more costly for my family to prepare me for marriage. First, I would not have enough time to work before marriage and help myself, and also a groom with higher education and status would want a more costly gehaz from my family.

The mother of a good student who had the chance to go to a university remarked: If [Rasha] had gone to university, she wouldn't have been able to prepare herself for marriage. She married when she was 23 years old. She is not young. She worked in the investment zone for six years after finishing her high-school diploma in order to prepare for marriage. No one of us would help Rasha in her marriage preparation. If she had gone to university, she would have graduated at 22, which means she would not have had the chance to work and help herself.

Another respondent who left school to work said:

I was good in school, but we are poor, and people started to propose to me. If I had continued my education, I would not have been able to have time to prepare myself for marriage. 
The narratives suggest that women who work to prepare for marriage must be willing to save from an early age regardless of their level of income. In addition to saving most of their income, workers are also able to supplement their income by joining a rotating savings pool in their workplace, in their neighborhood, or by proxy through a family member. The need to work and save, particularly after a girl has made a commitment to contributing large installments to a savings pool, holds several implications for their working lives as well. They feel compelled to hold on to their jobs, however they are treated and whatever the terms of their contracts. Women who need to earn as much as possible see little advantage in making an investment in order to acquire skills that may reap them benefits in the future. With the goal of marriage in mind, girls must be mindful of preserving their reputations. In most of Egypt, doing so requires that they work or travel at night; for some, it may also mean avoiding jobs that involve being seen in public or working with men.

\section{CONCLUSION}

What might explain the nature of marriage aspirations among female wage-workers in Egypt? Data on trends in marriage show that, for both sexes, weddings are being delayed for a variety of reasons. Young women remain single for some time after they leave school; usually during this period they enter the workforce. Despite the Egyptian government's implementation of a structural adjustment program that has influenced labor markets, no positive growth has been seen in work opportunities for young women such as have been observed in other countries. Instead, evidence of declining opportunities is clear even as larger numbers of young people complete their education and seek employment. The terms of employment are becoming less attractive and work conditions harsher than they have been in the past. The respondents' comments concerning marriage, meanwhile, reveal that aspirations for a higher standard of living are rising. For young women, these aspirations are most likely to be fulfilled by a well-planned marriage for which they can enlist the help of their families in preparations requiring considerable resources. Our qualitative data, as well as the work of others, suggest that Egyptian families mobilize their resources to help their offspring prepare for marriage and their new households. 


\section{Note}

1 Inclusion of unpaid workers does not greatly alter the distribution for any sector other than agriculture, where unpaid work increased substantially, leading to an increase from 1.45 million workers in 1988 to 2 million in 1998.

\section{References}

Abdelrahman, A.I. and S. Philip Morgan. 1987. "Socioeconomic and institutional correlates of family formation: Khartoum, Sudan, 1945-1975." Journal of Marriage and the Family 49(2): 401-412.

Amin, Sajeda, Ian Diamond, Ruchira T. Naved, and Margaret Newby. 1998. "Transitions to adulthood of female garment-factory workers in Bangladesh." Studies in Family Planning 29(2): 185-200.

Becker, Gary. 1991. A Treatise on the Family. Enlarged edition. Cambridge, MA: Harvard University Press.

Caldwell, John C. 1982. Theory of Fertility Decline. London: Academic Press.

Coale, Ansley J. 1989. "A reassessment of fertility trends, taking account of the Egyptian Fertility Survey," in Awad M. Hallouda, Samir Farid, and Susan H. Cochrane (eds.), Egypt: Demographic Responses to Modernization. Cairo: Central Agency for Public Mobilization and Statistics.

Hoodfar, Homa. 1997. Between Marriage and the Market: Intimate Politics and Survival in Cairo. Berkeley: University of California Press.

Malhotra, Anju and Amy Ong Tsui. 1996. "Marriage timing in Sri Lanka: The role of modern norms and ideas." Journal of Marriage and the Family 58(2): 476-490.

Mensch, Barbara S., Judith Bruce, and Margaret E. Greene. 1998. The Uncharted Passage: Girls' Adolescence in the Developing World. New York: The Population Council.

Oppenheimer, Valerie Kincade. 1997. "Women's employment and the gain to marriage: The specialization and trading model." Annual Review of Sociology 23: 431-453. 
Rashad, Hoda and Magued Osman. 2000. "Nuptiality in Arab countries: Changes and implications." Paper presented at Cairo symposium on The New Arab Family, 67 May organized by the Social Research Center, American University, Cairo and Cairo Papers in Social Science.

Sassler, Sharon and Robert Schoen. 1999. "The effect of attitudes and economic activity on marriage." Journal of Marriage and the Family 61(February): 147-159.

Singerman, Diane and Barbara Ibrahim. 2002. "The cost of marriage in Egypt: A hidden variable in the new Arab demography." Cairo Papers in Social Science. Cairo: AUC Press.

Singerman, Diane and Homa Hoodfar (eds.). 1996. Development, Change, and Gender in Cairo: A View from the Household. Bloomington, IN: Indiana University Press.

Smith, David P. 1980. “Age at first marriage.” World Fertility Survey Comparative Studies: Cross National Summaries. Voorberg, Netherlands and London: International Statistical Institute and World Fertility Survey.

Waite, Linda J. and Glenna D. Spitze. 1981. "Young women's transition to marriage." Demography 18(4): 681-694.

Wolf, Diane Lauren. 1992. Factory Daughters: Gender, Household Dynamics, and Rural Industrialization in Java. Berkeley, CA: University of California Press. 


\title{
POLICY RESEARCH DIVISION WORKING PAPERS
}

\author{
Recent Back Issues
}

144 John Bongaarts, "Household size and composition in the developing world."

145 John B. Casterline, Zeba A. Sathar, and Minhaj ul Haque, "Obstacles to contraceptive use in Pakistan: A study in Punjab."

146 Zachary Zimmer, Albert I. Hermalin, and Hui-Sheng Lin, "Whose education counts? The impact of grown children's education on the physical functioning of their parents in Taiwan."

147 Philomena Nyarko, Brian Pence, and Cornelius Debpuur, "Immunization status and child survival in rural Ghana."

*148 John Bongaarts and Zachary Zimmer, "Living arrangements of older adults in the developing world: An analysis of DHS household surveys."

149 Markos Ezra, "Ecological degradation, rural poverty, and migration in Ethiopia: A contextual analysis."
150 Cynthia B. Lloyd, Sahar El Tawila, Wesley H. Clark, and Barbara S. Mensch, "Determinants of educational attainment among adolescents in Egypt: Does school quality make a difference?"

151 Barbara S. Mensch, Paul C. Hewett, and Annabel Erulkar, "The reporting of sensitive behavior among adolescents: A methodological experiment in Kenya."

152 John Bongaarts, "The end of the fertility transition in the developed world."

153 Mark R. Montgomery, GebreEgziabher Kiros, Dominic Agyeman, John B. Casterline, Peter Aglobitse, and Paul Hewett, "Social networks and contraceptive dynamics in southern Ghana."

*154 Paul C. Hewett and Mark R. Montgomery, "Poverty and public services in developing-country cities."

* No longer available 
155 Zachary Zimmer, Linda G. Martin, and Ming-Cheng Chang, "Changes in functional limitations and survival among the elderly in Taiwan: 1993, 1996, and 1999."

156 John Bongaarts and Griffith Feeney, "How long do we live?"

157 Zachary Zimmer and Sovan Kiry Kim, "Living arrangements and socio-demographic conditions of older adults in Cambodia."

158 Geoffrey McNicoll, "Demographic factors in East Asian regional integration."

159 Carol E. Kaufman, Shelley Clark, Ntsiki Manzini, and Julian May, "How community structures of time and opportunity shape adolescent sexual behavior in South Africa."

*160 Julia Dayton and Martha Ainsworth, "The elderly and AIDS: Coping strategies and health consequences in rural Tanzania."

161 John Bongaarts, "The end of the fertility transition in the developing world."
162 Naomi Rutenberg, Carol E. Kaufman, Kate Macintyre, Lisanne Brown, and Ali Karim, "Pregnant or positive: Adolescent childbearing and HIV risk in South Africa."

163 Barbara S. Mensch, Wesley H. Clark, and Dang Nguyen Anh, "Premarital sex in Vietnam: Is the current concern with adolescent reproductive health warranted?"

164 Cynthia B. Lloyd, Cem Mete, and Zeba A. Sathar, "The effect of gender differences in primary school access, type, and quality on the decision to enroll in rural Pakistan."

165 Kelly Hallman, Agnes R. Quisumbing, Marie Ruel, and Bénédicte de la Brière, "Childcare, mothers' work, and earnings: Findings from the urban slums of Guatemala City."

*166 Carol E. Kaufman and Stavros E. Stavrou, "Bus fare, please': The economics of sex and gifts among adolescents in urban South Africa."

*167 Dominic K. Agyeman and John B. Casterline, "Social organization and reproductive behavior in southern Ghana." 
168 Paul C. Hewett, Annabel S. Erulkar, and Barbara S. Mensch, "The feasibility of computer-assisted survey interviewing in Africa: Experience from two rural districts in Kenya."

169 Zachary Zimmer and Julia Dayton, "The living arrangements of older adults in sub-Saharan Africa in a time of HIV/AIDS."
170 Ravai Marindo, Steve Pearson, John B. Casterline, "Condom use and abstinence among unmarried young people in Zimbabwe: Which strategy, whose agenda?"

171 Sajeda Amin and Nagah H. AlBassusi, "Wage work and marriage: Perspectives of Egyptian working women." 